\title{
A Holistic Assessment of Construction and Demolition Waste Management in the Nigerian Construction Projects
}

\author{
Ademilade Aboginije ${ }^{1, *}\left(\mathbb{D}\right.$, Clinton Aigbavboa ${ }^{2,3}$ and Wellington Thwala ${ }^{2}$ \\ 1 School of Civil Engineering and the Built Environment, University of Johannesburg, \\ Johannesburg 2092, South Africa \\ 2 Department of Construction Management and Quantity Surveying, Doornfontein Campus, \\ Johannesburg 2028, South Africa; caigbavboa@uj.ac.za (C.A.); didbhukut@uj.ac.za (W.T.) \\ 3 Sustainable Human Settlement and Construction Research Centre, House No 6, Research Village, \\ Bunting Road Campus, University of Johannesburg, Johannesburg 2001, South Africa \\ * Correspondence: aboginijeademilade@gmail.com; Tel.: +27-736-407-866
}

Citation: Aboginije, A.; Aigbavboa, C.; Thwala, W. A Holistic Assessment of Construction and Demolition Waste Management in the Nigerian Construction Projects. Sustainability 2021, 13, 6241. https://doi.org/ $10.3390 /$ su13116241

Academic Editor: Jose Navarro Pedreño

Received: 28 December 2020

Accepted: 19 January 2021

Published: 1 June 2021

Publisher's Note: MDPI stays neutral with regard to jurisdictional claims in published maps and institutional affiliations.

Copyright: (c) 2021 by the authors. Licensee MDPI, Basel, Switzerland. This article is an open access article distributed under the terms and conditions of the Creative Commons Attribution (CC BY) license (https:// creativecommons.org/licenses/by/ $4.0 /)$.
Abstract: This study provides a holistic assessment of the current waste management strategies implemented in Nigerian construction projects. The data used in this study were collected from both primary and secondary sources. The primary data were collected through survey questionnaires distributed via emails of the targeted respondents who are construction professionals in the study area of Lagos metropolis, while the secondary data were collected via the review of related literature. Out of the 200 questionnaires distributed, only 168 valid forms were retrieved. The collected data accounted for $84 \%$ of the entire survey and were suitable for the analysis. An exploratory factor analysis was conducted while the reliability of the research survey instrument was tested using Cronbach's alpha coefficient reliability. The result indicated that the waste management strategies were clustered into three groups, comprising practical legal framework and modular construction, sustainable procurement and material optimisation, and proper construction detailing and design. In conclusion, the waste management strategies implemented in Nigeria were assessed as being "not sustainable enough". However, it is recommended that there is an upgrading in either the approach or method of application of waste management strategies in order to ensure its sustainability.

Keywords: construction industry; construction and demolition waste; exploratory factor analysis; pattern matrix; sustainable development; waste management

\section{Introduction}

In most cases, materials that are generated when new building and civil engineering structures are built, and also when current buildings and civil-engineering structures are renovated or demolished with deconstruction activities, are referred to as "construction and demolition waste" (C\&DW). Such civil-engineering structures comprise every public building project such as street drainages, road or highways, bridges, utility plants, and dams [1]. However, waste material generation is a prominent issue in construction projects, and the adverse effect of waste has influenced the management of C\&DW in many countries. Shen et al. [2] stated that C\&DW is the major contributor to nearly $15-30 \%$ of the entire volume of waste that is disposed in several landfill sites in most countries, but this figure is bound to increase to approximately $40 \%$ when taking into consideration the amount of C\&DW generated in construction per tonnes per day.

In construction sites, waste generated retains major quantities of $C \& D W$ produced every year in any construction sectors, and waste generated in construction sites initiate the result in cost factors for the contractors such as cost incurred in transportation, waste disposal, and procurement [3-5]. However, it is expected that a drop in the volume of waste on construction sites can lead to a reduction in cost spent for raw material purchase and charges paid for disposal of the waste in landfill sites [6]. However, it is acceptable 
worldwide that waste management is important to a sustainable construction economy, and this involves a procedure in which waste production is controlled and minimised by employing expert builders and contractors. For instance, in an estimation, it is opined that nearly $80 \%$ of waste stream created on site is recyclable and usable [7-9].

However, the C\&DW sector has greatly relied on factors such as increase in population, development in urban areas, and/or levies paid on landfills in some regions. Vergara and Tchobanoglous [10] indicated that to avert the adverse effect of waste, suitable design and control is important. In addition, a proper structure for sustainable waste management implementation becomes an integral responsibility. This is a desirable trait in order to achieve a safe and protected environment in several countries [11]. However, the key significance of a sustainable C\&DW management strategies is to provide a tool for construction engineers, planners, and contractors to determine the best scenario for a sustainable minimisation of waste on construction sites $[12,13]$. Thus, the requirement for every construction industry with a good attribute of sustainable development is a sustainable C\&DW management strategies [14].

Consequently, managing C\&DW implies eradicating the waste where feasible, reducing waste where realistic, plus possible reuse of the materials, which can turn out to be waste; thereby, a colossal part of C\&DW can relentlessly be reused and recycled, and hence it preserves landfill size, for instance, waste generated from concrete or brick neglect or stones can be recycled into granular and fine aggregate, such as recycled aggregate concrete, cement, and floor thatches [15-18]. The UK Waste and Resources Action Programme (WRAP) in 2017 states that a good practice of material waste management gives a series of benefits that includes reduction in material and disposal costs, increase in competitive differentiation, increase in performance against corporate sustainability responsibility objectives, lower carbon dioxide $\left(\mathrm{CO}_{2}\right)$ emissions, meeting planning requirements, the complementary gains when combined with other aspects of sustainable design, and responses to and pre-empting public policy [4,5].

In China, the government establishes waste management policies and regulations that requires contractors to prepare and implement a waste management system and carry out on-site sorting of waste before certain payments are made, which is seen as tool to minimise waste incurred in construction projects [14,19-21]. However, in the absence of procedure in providing guidelines on how to produce a suitable waste management plan, the development of a waste management-mapping model that can be integrated before the commencement of construction activities and the provision of specification for the various handling measures for managing waste onsite is the cause of major waste production in the country [22-24]. According to Poon et al. [25], every regulation is required in the construction sectors to be followed and applied towards sustainable waste management, and there is a need to develop a holistic waste management system that is cost-effective, sustainable, and acceptable, with an emphasis on environmental conservation and good technological selection without the impact of the government regulations [26-28].

In most cases, waste normally emanates during different life-cycle phases in construction, i.e., during the planning, construction, and demolition stages. Moreover, in procurement, not all the materials are used during construction, indicating that the leftovers may remain as waste that may not be accounted for [23,29]. In Nigeria, large volume of waste is generated in construction sites, especially in the Lagos metropolis. This is due to its position as Nigeria's commercial nerve centre, with it continuing to experience rapid population growth, projected at $6-8 \%$ per annum. In this regard, the causes of materials waste in Nigerian construction sites include poor site supervision, design error, defective materials, unskilled labour, poor quality of materials, changes in design, specification errors, poor storage facilities, poor handling process, poor material scheduling, wrong suppliers' advice, and bulk purchase that leads to excess and consequently contributes to waste generation in construction sites [30-32].

In addition, inadequate involvement of non-regulatory sectors in the collection of the waste, lack of sustainable waste management plan, and the valuation of waste that could 
begin from the design processes is not usually considered in construction in Nigeria, and poor implementation of a sustainable procurement system is one of the major influencing factors to waste generation [33-35].

However, the participation of informal private sectors in the disposal of waste has made the environment civilised, but in order to have accurate data of the amount of waste being generated, a proper survey should be examined [36-38]. According to the survey carried out by the Waste Management Authority in Lagos (LASMA), the landfill sites have been regulated to ensure waste material handling and control system over a decade. In the survey report, there are five landfill sites in Lagos metropolis in the three major sites and several temporary sites, where all types of waste are disposed including waste from demolition and construction $[39,40]$. The composition of this waste comprises concrete, reinforcement steel, plywood, plastics, and other packaging materials. According to Aboginije [3], waste from concrete, reinforcement, and wood is indicated as the highest waste generated in Nigerian construction projects, generating rates that range between $15-20 \%$, while soil and stones, plastic, and packing materials are the least, with $2-4 \%$ generating rates, as indicated in Figure 1.

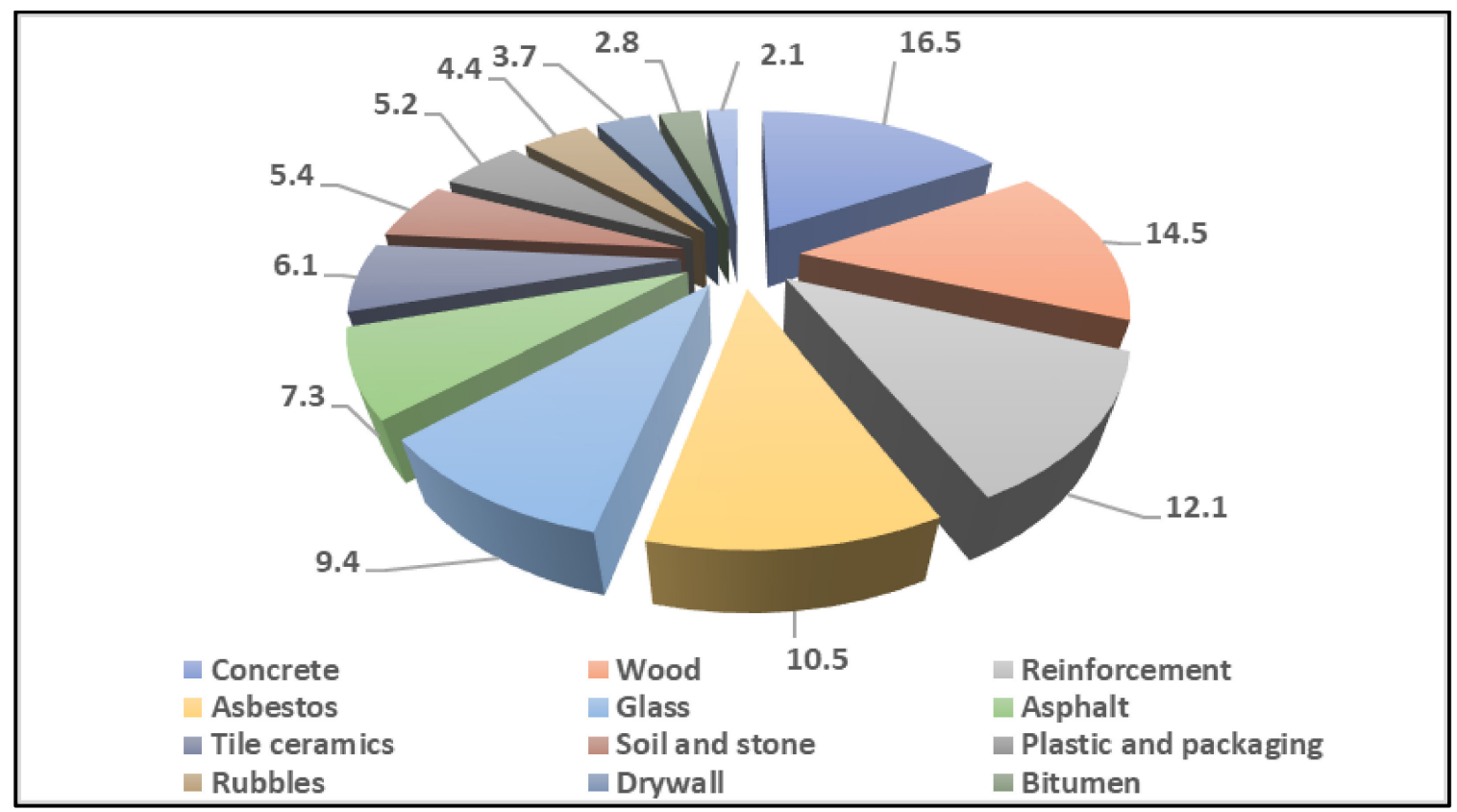

Figure 1. Percentage (\%) composition of waste in Nigeria [3].

According to Ajayi et al. [41], the process of handling of waste involves identifying waste stream, evaluating waste on-site, deciding the final destination of waste materials, segregating waste, and careful studying of the handling procedures on-site. The waste streams are the flow of the waste that are specified right from their sources through recovery and recycling to the final disposal. However, waste framework and legislative structure must be instituted if any sustainable waste sector is to be achieved [42,43]. Many countries are now developing a waste framework directive to curb the adverse effect of waste. According to a report by the European Environmental Agency, most of the EU has established and implemented a framework that can lead to a recycling rate of about $90 \%$ [26]. Recently, the Nigerian government aimed at developing a sustainable waste management legislation to curb the generation and adverse effects of waste on its environment, but there are still problems yet to be tackled in terms of this reality [44,45]. In addition, the waste management system must be understood and accepted by all concerned before its implementation. Thus, staff training, communicating with staff, and obtaining their commitment towards ensuring waste management plans is actualised are essential parts of the implementation processes [46]. 
In this study, the main purpose was to carry out a holistic investigation with the intention of assessing the current C\&DW management strategies implemented to minimise waste in the Nigerian construction projects.

\section{Materials and Methods}

This study's overall research approach is illustrated in Figure 2. The first step, i.e., planning, shows that a review of literature was conducted on the basis of the research aim and a set of identified variables. Thus, 20 variables were selected as the most appropriate C\&DW management strategies to be implemented in the construction projects. However, using a Likert scale ranking, we ranked the selected variables accordingly. Subsequently, an exploratory factor analysis (EFA) was conducted, and results were interpreted.

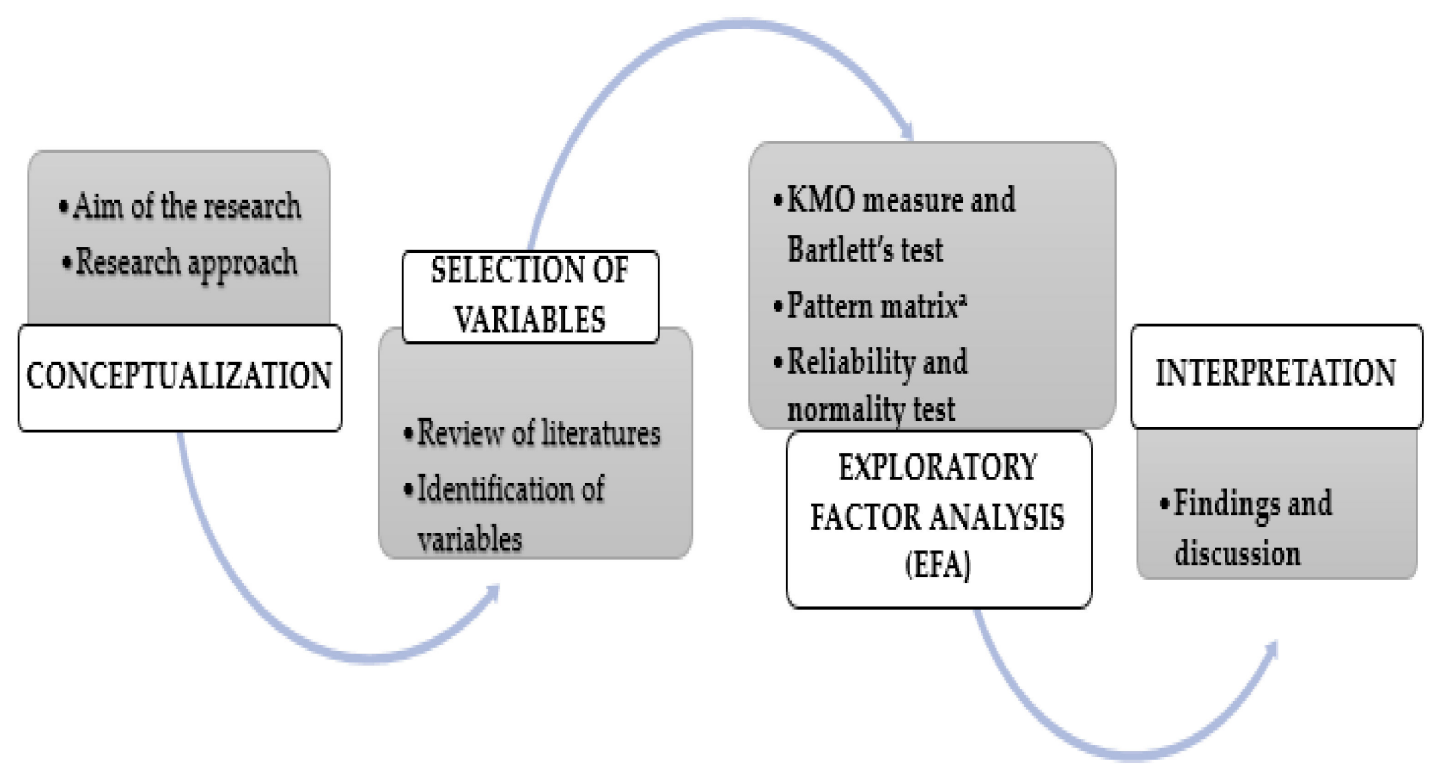

Figure 2. Overall research procedure.

\subsection{Study Area}

The research was conducted in Lagos metropolis, Nigeria. The metropolis is one of the urban cities located in the southwestern part of Nigeria around latitudes 6022-42 N and longitude $2042^{\prime} \mathrm{E}$. The humid tropical climate known as monsoon tropical climate is characterised by 2 rainy (between April-July and September-November) and 1 dry (December-March) seasons. Mean annual rainfall ranges between 1382 and $2733 \mathrm{~mm}$, with an average of $2500 \mathrm{~mm}$, while monthly rainfall ranges between $25 \mathrm{~mm}$ and more than 400 $\mathrm{mm}$. The maximum temperature varies between 30 and $34^{\circ} \mathrm{C}$, while the minimum temperature varies between 23 and $27^{\circ} \mathrm{C}$. The relative humidity is about $70 \%$ high throughout the year [14]. Lagos state is part of the southwest zone, which is part of the six geopolitical zones in Nigeria, with its capital in Ikeja. Lagos is the nation's largest urban area in Nigeria. It is a major financial centre and there are many construction companies, with nearly $60 \%$ of construction activities taking place in Lagos. Likewise, Lagos comprises 20 local government areas and it is a major determinant of the largest volume of C\&DW generated in the Nigerian construction sector due to its population growth and industrialisation [12,47].

Presently, the population of Lagos is projected at 21 million people with a density of 6050 per $\mathrm{km}$, thus generating approximately 13,000 tons of municipal waste, of which 70 percent of its volume end in landfill sites across the metropolis as illustrated by Figure 3 [48]. However, these landfill sites are still in operation in Lagos with the increasing urban development, being due to lack of decisive action by the government to increase the levies paid by landfill operators. The inefficient management of waste due to poor urban planning, inadequate policy framework, and legal structures that can effectively manage the waste 
consequently result into large amount of waste disposed in various landfill site in the metropolis of Lagos. Although this large amount of waste disposed in several landfill sites in Lagos is peculiar to every urban city in the country [49].

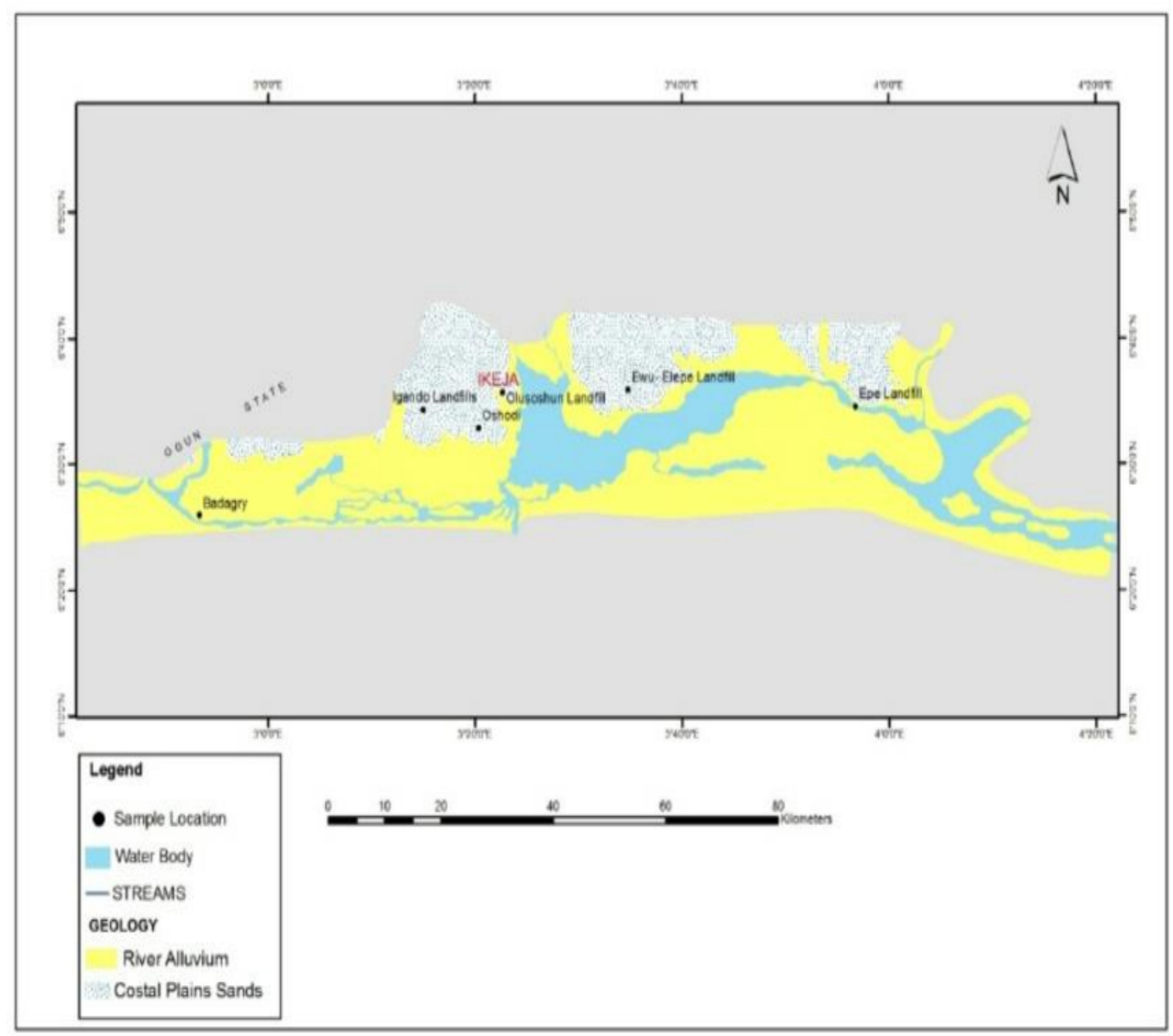

Figure 3. Map of Lagos state and locations of landfill sites [49].

\subsection{Survey Instrument}

The data used were collected through primary and secondary sources of data collection. According to Creswell [50], the data collection stage is vital in achieving the objectives of any research investigation because it involves gathering all the required information from the important sources. The primary data collected for this study was generated by administering well-structured questionnaires, which are mostly used for quantitative research [51]. However, the secondary data were obtained by making use of current literature published in conference papers, government reports, and journal articles. Data were collected from construction professionals in the various construction firms in Lagos, of which out of 200 questionnaires distributed, a total of 168 questionnaires were received back from the participants. The rationale for the quantitative survey employed was due to a relatively short period of time wherein the data was collected (See Supplementary Materials).

In 87 days (between May to July, 2020), a large portion of the sample population was reached. These data were collected via emails due to the impact of the global pandemic (COVID-19), although the approach further makes use of a standard research design and fixed procedures, making it possible to gather information needed for this study. A quantitative method was employed so as to achieve the purpose of the study, helping to 
indicate the C\&DW management strategies implemented to minimise the waste in the Nigerian construction projects. In this study, the population was composed of quantity surveyors, architects, civil engineers, project managers, civil engineers, and builders in the construction firms within Lagos metropolis, Nigeria.

\subsection{Data Analysis}

According to Neuman [51], data analysis can be described as a practice that involves the best way to convey orders, organisation, and significance of the bulk of data collected in a vital research aspect. In this study, collected data were analysed using descriptive statistics methods. However, the statistics techniques of EFA were performed to collect information about the one-dimensionality of the factors in order to yield their factor analysability. According to Pallant [52], factor analysis is dissimilar from other methods, such as regression. It is not scheduled to test a hypothesis to determine whether a group is essentially different from another, but it takes a larger group of variables and looks for a method through which the data may be minimised or reduced. This makes use of a smaller set of factors or components. It does this by looking for clumps or groups amongst the inter-correlations of set variables. Therefore, this study considered EFA as appropriate to group the variables into clusters which explains the situation of C\&DW management strategies in the Nigerian construction projects.

\section{Results}

\subsection{Demographic Information}

The respondents consisted largely of males, comprising $73.8 \%$ of the total retrieved data sample, with females comprising $25 \%$, and $1.2 \%$ preferred not to specify their gender. Furthermore, there was an almost even distribution of the professionals (i.e., civil engineers, builders, quantity surveyors, project managers, and architects) to ensure there was no form of bias with any of the professionals making up the larger percentage of the sample population. On average, the respondents had more than 15 years of experience, and their minimum qualification was a bachelor's degree. The majority of the respondents worked in both public consulting and contracting firms, followed by private organisation firms, whereas government establishments had the lowest number of respondents.

Furthermore, $29.2 \%$ of the respondents had worked on housing estate projects, $17.0 \%$ had worked on road construction, and $12.5 \%$ had worked on government offices, whereas $4.2 \%$ had worked on civil works, $3.1 \%$ had worked on renovation, and $1.1 \%$ had worked on other construction projects. Most of the respondents had a high degree of experience in C\&DW management practices, with $83.9 \%$ signifying their involvement in C\&DW management practices in the past two years. In addition, their educational qualification and years of experiences indicated that their opinion can be relied upon and can be valid with regards to the questions and objectives of this study. The demographic findings as presented in Table 1 show the exact sample of the targeted population in this research study without any distortions.

\subsection{Mean Item Score}

The respondents' ranking of their perceptions on the C\&DW management strategies implemented in the Nigerian construction projects is detailed. The respondents were requested to indicate the extent to which each construction and demolition waste management strategy was used, using a five-point scale: 1 = to no extent, 2 = small extent, 3 = moderate extent, 4 = large extent, and 5 = very large extent (See Supplementary Materials). "Re-use of materials as backfills" was ranked highest, with a mean of 4.24 and standard deviation of 0.837 . The second-ranked challenge was the "off-site preparation, pre-assembly, and prefabrication", with a mean of 4.05 and a standard deviation of 0.904 . "Provision of detailed information on drawings" was ranked third, with a mean of 3.83 and a standard deviation of 0.680 . Ranked fourth was "building information modelling (BIM) implementation", with a mean of 3.82 and a standard deviation 1.019. Ranked fifth 
was "avoiding frequent design changes", with a mean of 3.74 and a standard deviation of 0.791 , and ranked sixth was "reduction of waste at the material source", with a mean of 3.73 and a standard deviation 0.723 .

Table 1. Demographic information.

\begin{tabular}{ccc}
\hline Description & Indication & Percentage \\
\hline \multirow{3}{*}{ Gender } & Male & 73.8 \\
& Female & 25.0 \\
& Prefer not to indicate & 1.2 \\
\hline \multirow{2}{*}{ Projects undertaken } & Housing estates & 29.2 \\
& Road construction & 17.0 \\
& Government offices & 12.5 \\
& School & 10.1 \\
& Shopping complex & 4.5 \\
& Hospitals & 4.3 \\
& Civil works & 4.2 \\
& Stadia & 3.5 \\
Professions & Renovations & 3.2 \\
& Other projects & 1.1 \\
\hline & Civil engineers & 27.4 \\
& Quantity surveyors & 22.6 \\
& Builders & 17.9 \\
& Architects & 17.9 \\
& Project managers & 14.3 \\
\hline
\end{tabular}

"Provision for off-site construction in the design phase" was ranked seventh, with a mean of 3.72 and a standard deviation of 0.966 ; ranked eighth was "improving the on-site waste management plan", with a mean of 3.70 and a standard deviation of 0.801 . The ninthranked C\&DW management strategy used in the Nigerian construction projects was "use of standard dimension and sizes in design", with a mean of 3.68 and a standard deviation of 0.814 , and ranked tenth was "appropriate specifications on reusable, reclaimable, and recycled materials", with a mean of 3.63 and a standard deviation of 0.919. Ranked 11th was "complete and unambiguous contract documents", with a mean of 3.62 and a standard deviation of 0.727 , and ranked 12th was "on-site sorting of materials", with a mean of 3.61 and a standard deviation of 0.726 . "Provision for off-site construction in the design phase" was ranked 13th, with a mean of 3.58 and a standard deviation of 0.808 ; "avoidance of late drawings, revisions, and submissions" ranked 14th, with a mean of 3.54 and a standard deviation of 0.788 ; and "provision for deconstruction and disassembly in the design phase" ranked 15th, with a mean of 3.43 and a standard deviation of 0.859 .

"Provision for material optimisation in the design phase" was ranked 16th, with a mean of 3.40 and standard deviation of 0.786 , while "establishment of waste separation and collection techniques" was ranked 17th, with a mean of 3.35 and a standard deviation of 0.882. "Government intervention through landfill tax" and "provision for waste efficient procurement in the design phase" both had a mean of 3.32 and standard deviations of 0.949 and 0.843 respectively, while the lowest ranked- "adding waste minimisation in contractual clauses", with a mean of 3.26 and a standard deviation of 0.929-ranked 20th Table 2 shows the descriptive statistics of C\&DW management strategies implemented in the Nigerian construction projects. 
Table 2. Descriptive statistics.

\begin{tabular}{cccc}
\hline Construction and Demolition Waste Management Strategies & Mean & $\begin{array}{c}\text { Standard } \\
\text { Deviation }\end{array}$ & Rank \\
\hline Re-use of materials as backfills & 4.24 & 0.837 & 1 \\
Off-site preparation, pre-assembly, and prefabrication & 4.05 & 0.904 & 2 \\
Provision of detailed information on drawings & 3.83 & 0.608 & 3 \\
BIM implementation & 3.82 & 1.019 & 4 \\
Avoiding frequent design changes & 3.74 & 0.791 & 5 \\
Reduction of waste at the material source & 3.73 & 0.723 & 6 \\
Provision for off-site construction in the design phase & 3.72 & 0.966 & 7 \\
Improving the on-site waste management plan & 3.70 & 0.801 & 8 \\
Use of standard dimension and sizes in design & 3.68 & 0.814 & 9 \\
Appropriate specifications on reusable, reclaimable, and & 3.63 & 0.919 & 10 \\
recycled materials & 3.62 & 0.727 & 11 \\
Complete and unambiguous contract documents & 3.61 & 0.726 & 12 \\
On-site sorting of materials & 3.58 & 0.808 & 13 \\
Provision for off-site construction in the design phase & 3.54 & 0.788 & 14 \\
Avoidance of late drawings, revisions, and submissions & 3.43 & 0.859 & 15 \\
Provision for deconstruction and disassembly in the design phase & 3.40 & 0.726 & 16 \\
Provision for material optimisation in the design phase & 3.35 & 0.882 & 17 \\
Establishment of waste separation and collection techniques & 3.32 & 0.843 & 18 \\
Government intervention through landfill tax & 3.32 & 0.949 & 18 \\
Provision for waste efficient procurement in the design phase & 3.26 & 0.929 & 20 \\
Adding waste minimisation in contractual clauses & &
\end{tabular}

\subsection{Exploratory Factor Analysis (EFA)}

\subsubsection{Measure of Sampling Adequacy}

To carry out the EFA, we established the suitability of data by inspecting the correlation matrix to indicate the coefficient value of 0.4 and above, which was suitable for factor analysis. The Kaiser-Meyer-Olkin (KMO) measure of sampling adequacy was used to show the adequacy of the distribution of values in order to proceed with EFA. According to Pallant [51], data distribution measure of 0.6 is acceptable for the EFA. Table 3 shows that the KMO value was 0.927 , which was above the acceptable 0.6 , while the Bartlett's test of sphericity revealed that there was a statistical significance in the variables with value $(0.000)$ less than 0.050 , making them factorable. The correlation matrix table showed that there was a correlation coefficient $>0.3$, which supported the KMO and Bartlett's test for the factorability of the datasets.

Table 3. Kaiser-Meyer-Olkin (KMO) measure and Bartlett's test.

\begin{tabular}{lcc}
\hline \multicolumn{2}{c}{ Kaiser-Meyer-Olkin Measure of Sampling Adequacy } & $\mathbf{0 . 9 2 7}$ \\
\hline \multirow{3}{*}{ Bartlett's test of sphericity } & \multicolumn{2}{c}{ Approximate chi-squared } \\
\cline { 2 - 3 } & Df & 2218.378 \\
\cline { 2 - 3 } & Sig. & 168 \\
\hline
\end{tabular}

\subsubsection{Pattern Matrix}

The steep slope displayed the large factor whereas the gradual trailing off revealed the rest of the factors that have an eigenvalue lower than 1 . Two clusters of factors were positioned on the slope, and they were retained. Table 4 indicates the pattern matrix that displays the factor loadings of each of the variables. The highest loading items on the factors are shown. 
Table 4. Pattern matrix ${ }^{a}$.

\begin{tabular}{|c|c|c|c|}
\hline & 1 & 2 & 3 \\
\hline Establishment of waste separation and collection techniques & 0.780 & & \\
\hline $\begin{array}{l}\text { Appropriate specifications on reusable, reclaimable, and } \\
\text { recycled materials }\end{array}$ & 0.744 & & \\
\hline Provision for deconstruction and disassembly in the design phase & 0.703 & & \\
\hline Creating awareness among contractors & 0.551 & & \\
\hline BIM implementation & 0.524 & & \\
\hline Government intervention through landfill tax & 0.502 & & \\
\hline Off-site preparation, pre-assembly, and prefabrication & 0.471 & & \\
\hline Reduction of waste at the material source & & 0.753 & \\
\hline Improving the on-site waste management plan & & 0.636 & \\
\hline Adding waste minimisation in contractual clauses & & 0.629 & \\
\hline Provision for waste efficient procurement in the design phase & & 0.596 & \\
\hline Provision for off-site construction in the design phase & & 0.572 & \\
\hline Provision for material optimisation in the design phase & & 0.562 & \\
\hline Re-use of materials as backfills & & 0.551 & \\
\hline On-site sorting of materials & & 0.531 & \\
\hline Avoidance of late drawings, revisions, and submissions & & 0.528 & \\
\hline Complete and unambiguous contract documents & & 0.410 & \\
\hline Use of standard dimension and sizes in design & & & 0.688 \\
\hline Provision of detailed information on drawings & & & 0.630 \\
\hline Avoiding frequent design changes & & & 0.588 \\
\hline
\end{tabular}

\subsubsection{Reliability and Normality Test}

A reliability test was carried out on the variable clusters, which indicated that the variables measured were valid for the cluster they belonged to. In addition, a normality test was carried out on the compared groups to ascertain whether they were distributed normally or not. In this study, 0.05 was used as the lowest value for normality tests. Sample sizes from 50 and above use the Kolmogorov-Smimov statistics results, while for sample sizes that were less than 50 , usually the Shapiro-Wilk statistics results are used. In this study, the sample size was greater than 50 ; therefore, Kolmogorov-Smimov statistics results were used. Table 5 shows both the reliability and normality test for the factor clusters.

Table 5. Clusters' reliability and normality test.

\begin{tabular}{|c|c|c|c|c|c|c|c|}
\hline & \multirow{2}{*}{$\begin{array}{l}\text { Cronbach's Alpha } \\
\text { Coefficient }\end{array}$} & \multicolumn{3}{|c|}{ Kolmogorov-Smimov } & \multicolumn{3}{|c|}{ Shapiro-Wilk } \\
\hline & & Statistics & df & $p$-Value & Statistics & df & $p$-Value \\
\hline Legal framework and modular construction & 0.840 & 0.189 & 168 & 0.000 & & & \\
\hline Construction material optimisation & 0.826 & 0.248 & 168 & 0.000 & & & \\
\hline Construction detailing and design & 0.784 & 0.256 & 168 & 0.000 & & & \\
\hline
\end{tabular}

\section{Discussion}

To achieve the ideas of indicating the C\&DW management strategies implemented in the Nigerian construction projects, we carried out an exploratory factor analysis, producing three factor clusters. According to the results from Table 3 (see Section 3.3.2) showing the rotation matrices, the 20 variables were factored into 3 clusters, which were interpreted 
on the basis of the observed inherent relationship that exists among the variables in the clusters.

\subsection{Cluster Description}

\subsubsection{Cluster 1-Legal Framework and Modular Construction}

Seven variables were loaded onto cluster 1 , as shown in Table 3. These variables were "establishment of waste separation and collection techniques" (0.780); "appropriate specifications on reusable" (0.744); "reclaimable and recycled materials" (0.703); "provision for deconstruction and disassembly in the design phase" (0.551); "BIM implementation" (0.524); "government intervention through landfill tax" (0.502); and "off-site preparation, pre-assembly, and prefabrication" (0.471). All these variables can be observed to relate to waste management approaches implemented during the construction and execution phases of the projects. This factor cluster can therefore be termed as "legal framework and modular construction". This cluster had a total variance of $59.567 \%$, which makes it the most notable C\&DW management strategy implemented in the Nigerian construction industry.

This finding affirms that establishing waste separation and collection techniques will in due course reduce waste generated at each phase of construction. One of the ways in which waste can be controlled and minimised is to specify the appropriate re-use of waste materials on sites. Reclaimable and recyclable materials are used as an alternative to disposal in landfills. However, strict laws and expensive landfill levies imposed on landfill site disposals reduce the reliance on landfills, making those involved think of possible alternatives. In addition, the separation of materials is necessary to ensure pure, quality materials. Likewise, it is confirmed that proper material recovery through the provision for deconstruction and disassembly at the design phases in construction ultimately reduces the waste, even at that phase. However, off-site preparation, pre-assembly, and prefabrication are the best means of eliminating waste before the inception of construction activities on sites.

Off-site construction and prefabrication are carried out in construction projects in Nigeria, but the degree of adoption of the development is low in comparison to the total number of construction firms in the country. The increased awareness and implementation of the building information modelling (BIM) is also another modularity in construction, which obviously reduces, or eliminates, waste in construction. However, among the indicated waste management approaches in this cluster, the adoption of modularity in construction projects in Nigeria is still below standard and needs an upgrade in either the approach or method of application of these approaches to ensure the waste management systems are more sustainable.

\subsubsection{Cluster 2-Sustainable Procurement and Material Optimisation}

In the second cluster, there were 10 variables loaded onto it. These variables were "reduction of waste at the material source" (0.753), "improving the on-site waste management plan" (0.636); "adding waste minimisation in contractual clauses" (0.629); "provision for waste efficient procurement in the design phase" (0.596); "provision for off-site construction in the design phase" (0.572); "provision for material optimisation in the design phase" (0.562); "re-use of materials as backfills" (0.551); "on-site sorting of materials" (0.531); "avoidance of late drawings, revisions, and submissions" (0.528); and "complete and unambiguous contract documents" (0.410). All these variables can be observed to relate to waste generation during both the planning, design, and execution phases of the construction projects. This cluster was therefore labelled "sustainable procurement and material optimisation". Thus, with the total variance of $17.115 \%$, this cluster was ranked as the second strategy to C\&DW management used in the Nigerian construction industry behind the variables in cluster 1 .

This finding indicates that the sustainable procurement of materials by making provision for waste-efficient procurement in the design, reduction of waste at sources, optimising materials' re-use, and recovery will make waste elimination or avoidance possible. In addi- 
tion, on-site material sorting, separation for either re-use or recycling increases the usage of materials, hence reducing construction costs. However, many of the procurement procedures and the implementation are still deficient in reducing waste in the country. The contractual documents must contain waste minimisation, and no room should be given to contractual ambiguity. Likewise, it can be opined that the procurement of materials must be sustainable to eliminate waste, and if any country hopes to minimise waste generation, it must focus on the procurement policies and contract details of every construction project to make them eco-friendly. In addition, late drawings, revisions, and submissions must be avoided.

\subsubsection{Cluster 3-Construction Detailing and Design}

The third cluster consists of three variables, namely, "use of standard dimension and sizes in design" (0.688), "provision of detailed information on drawings" (0.630), and "avoiding frequent design changes" (0.588). All these factors relate with the cluster labelled "construction detailing and design". This cluster had a total variance of $15.885 \%$, which makes it the third ranked C\&DW management strategy in the Nigerian construction projects.

This finding indicates that in Nigerian construction projects, avoiding frequent changes in design, making use of standard dimensions and sizes in design, and ensuring the drawings are well detailed is key to sustainable construction projects. Lack of this concrete information provision on drawings by the architects and many unclear and drawings has resulted in misinterpretation, which has led to waste being generated in construction sites. However, site engineers must painstakingly take note of every detail in the drawings provided for the construction projects.

\subsubsection{Implication of Findings}

The management directive regarding the development of a sustainable waste management plan requires the involvement of experts and professionals who meet the requirements to supervise site operatives, as well as awareness among craftsmen and women to give them concrete information and training in practice. However, this can reduce C\&DW in a negligible manner. When the waste management approach is implemented, it can cause a reduction in the construction costs, improvement of output, and better storage and handling of materials transported to sites. In addition, the need for the application of proper construction detailing and precise design cannot be overemphasized. A high requirement of expertise should be in place when selecting civil engineers as site supervisors in order to ensure the process of design is not marred with errors that could possibly generate huge amounts of waste.

\section{Conclusions}

This study set out to investigate the C\&DW management strategies implemented in the Nigerian construction projects. The reviews of literature identified C\&DW management strategies implemented throughout the life cycle phases of the construction projects that consist of the establishment of waste separation and collection techniques, and appropriate specifications on reusable, reclaimable, and recycled materials. Likewise, provision for deconstruction and disassembly in the design phase; BIM implementation; government intervention through increased landfill tax; off-site preparation, pre-assembly, and prefabrication; reduction of waste at the material source; improving the on-site waste management plan; and adding waste minimisation in contractual clauses can contribute to C\&DW management. In addition, provision for efficient procurement in the design phase; provision for off-site construction in the design phase; provision for material optimisation in the design phase; re-use of materials as backfills; on-site sorting of materials; avoidance of late drawings, revisions, and submissions; and complete and unambiguous contract documents can make a difference to the management of waste. The use of standard dimensions and 
sizes in design, provision of detailed information on drawings, and avoidance of frequent design changes were also indicated in this study.

From the survey results obtained from respondents, the major waste management strategies implemented included re-use of materials as backfills; off-site preparation, preassembly, and prefabrication; provision of detailed information on drawings; and BIM implementation. The results show that the level of utilisation of some of these approaches is moderate, especially the adoption of modularity in construction projects in Nigeria, which is still below standard, while many of the procurement procedures and their implementation are still deficient in reducing waste in the country. However, the waste management still has some basic sustainability traits.

\title{
6. Recommendation
}

To ensure the waste management is sustainable in the Nigerian construction sector, an upgrading in either the approach or method of application is required. Furthermore, the procurement procedure and policies must focus on ways to eliminate or minimise waste. Site engineers must painstakingly take note of every detail in the drawings provided for the construction projects in Nigeria. In addition, awareness should be made to promote secondary material sales which thus expand the secondary market. Although this study focuses on an inclusive assessment of the waste management status quo in Nigeria, further research can consider the life cycle assessment tool to evaluate the performance of the C\&DW management system or/procedure using sustainability indicators and quantitatively collected data.

Supplementary Materials: The following are available online at https:/ / www.mdpi.com/article/10 $.3390 /$ su13116241/s1.

Author Contributions: Conceptualisation, C.A. and A.A.; methodology, A.A.; formal analysis, A.A.; investigation, A.A.; data curation, A.A.; writing—original draft preparation, A.A.; writing-review and editing, C.A. and W.T.; funding acquisition, C.A. All authors have read and agreed to the published version of the manuscript.

Funding: This research was sponsored by National Research Foundation, South Africa, grant number 118837.

Informed Consent Statement: Informed consent was obtained from all subjects involved in the study.

Data Availability Statement: The data presented in this study are available on request from the corresponding author.

Acknowledgments: The study contribution is part of the unpublished master's dissertation of the corresponding author program in the Department of Construction Management and Quantity Surveying, University of Johannesburg, South Africa.

Conflicts of Interest: The authors declare no conflict of interest. The funders had no role in the design of the study; in the collection, analyses, or interpretation of data; in the writing of the manuscript; or in the decision to publish the results.

\author{
Abbreviations \\ BIM Building information modelling \\ C\&DW Construction and demolition waste \\ EFA Exploratory factor analysis \\ LASWMA Lagos State waste management agency \\ WRAP Waste and Resources Action Programme \\ EU European Union \\ EEA European Environmental Agency
}




\section{References}

1. Nagapan, I.S.; Abul-Rahman, I.A.; Aziz, A.A. Construction waste management: Malaysian perspective. In Proceedings of the International Conference on Civil and Environmental Engineering Sustainability, Johor Bahru, Malaysia, 3-5 April 2012; pp. 299-309.

2. Shen, L.Y.; Tam, V.W.; Tam, C.M.; Drew, D. Mapping approach for examining waste management on construction sites. J. Constr. Eng. Manag. 2004, 130, 472-481. [CrossRef]

3. Aboginije, A.J. Assessment of Construction and Demolition Waste Management System in the Nigerian Construction Industry. Master's Dissertation, University of Johannesburg, Johannesburg, South Africa, 2020.

4. Abioye, A.; Rao, B. Sustainable approach to managing construction and demolition waste: An opportunity or a new challenge. J. Innov. Res. Sci. Eng. Technol. 2015, 4, 10368-10377. [CrossRef]

5. Aboginije, A.J.; Aigbavboa, C.O.; Thwala, W.; Samuel, S. Determining the impact of construction and demolition waste reduction practices on green building projects in Gauteng province, South Africa. In Proceedings of the International Conference of Industrial Engineering and Operation Management, Dubai, UAE, 10-12 March 2020; pp. 1027-1038.

6. Thomas, H.C. Solid Waste Technology and Management 1E2, 1st ed.; Blackwell Publishing Ltd.: Hoboken, NJ, USA, $2010 ;$ pp. 61-84.

7. Begum, R.A.; Satari, S.K.; Pereira, J.J. Waste generation and recycling: Comparison of conventional and industrialized building systems. Am. J. Environ. Sci. 2010, 6, 383-388. [CrossRef]

8. Ekanayake, L.L.; Ofori, G. Construction material waste source evaluation. In Proceedings of the 2nd Southern Africa Conference on Sustainable Development in the Built Environment, Pretoria, South Africa, 23-25 August 2000; pp. 1-6.

9. Huang, J.; Zhao, R.; Huang, T.; Wang, X.; Tseng, M.L. Sustainable municipal solid waste disposal in the belt and road initiative: A preliminary proposal for Chengdu city. Sustainability 2018, 10, 1147. [CrossRef]

10. Vergara, S.E.; Tchobanoglous, G. Municipal solid waste and the environment: A global perspective. Environ. Resour. 2012, 37, 277-309. [CrossRef]

11. Elgizawy, S.M.; El-Haggar, S.M.; Nassar, K. Approaching sustainability of construction and demolition waste using zero waste concept. Low Carbon Econ. 2016, 7, 1-16. [CrossRef]

12. Zhao, W.; Ren, H.; Rotter, V. A system dynamics model for evaluating the alternative of type in construction and demolition waste recycling center-the case of Chongqing, China. J. Resour. Conserv. Recycl. 2011, 55, 933-944. [CrossRef]

13. Hwang, B.G.; Yeo, Z.B. Perception on benefits of construction waste management in the Singapore construction industry. Eng. Constr. Archit. Manag. 2011, 18, 394-406. [CrossRef]

14. Tam, V.W.; Shen, L.Y.; Fung, I.W.; Wang, J.Y. Controlling construction waste by implementing governmental ordinances in Hong Kong. J. Constr. Innov. 2007, 7, 149-166. [CrossRef]

15. Ghiani, G.; Laganà, D.; Manni, E.; Musmanno, R.; Vigo, D. Operations research in solid waste management: A survey of strategic and tactical issues. Comput. Oper. Res. 2014, 44, 22-32. [CrossRef]

16. Xiao, S.; Dong, H.; Geng, Y.; Brander, M. An overview of China's recyclable waste recycling and recommendations for integrated solutions. Resour. Conserv. Recycl. 2018, 134, 112-120. [CrossRef]

17. Tongo, S.O.; Oluwatayo, A.A.; Adeboye, B.A. Factors influencing waste generation in buildings project in South-west, Nigeria. Int. J. Waste Resour. 2019, 10,1-4. [CrossRef]

18. Wahab, A.B.; Lawal, A.F. An evaluation of waste control measures in construction industry in Nigeria. Afr. J. Environ. Sci. Technol. 2011, 5, 246-254. [CrossRef]

19. Wang, R.; Li, S. Talking about the production and disposing of construction waste from the view of sustainable development. In Proceedings of the Power and Energy Engineering Conference (APPEEC), Wuhan, China, 25-28 March 2011; pp. 1-4. [CrossRef]

20. Yuan, H. Critical management measures contributing to construction waste management: Evidence from construction projects in china. Proj. Manag. J. 2014, 44, 101-112. [CrossRef]

21. Yuan, H. Barriers and countermeasures for managing construction and demolition waste: A case of Shenzhen in China. J. Clean Prod. 2017, 157, 84-93. [CrossRef]

22. Zhang, N.; Zheng, L.; Duan, H.; Yin, F.; Li, J.; Niu, Y. Differences of methods to quantify construction and demolition waste for less-developed but fast-growing countries: China as a case study. Environ. Sci. Pollut. Res. 2019, 26, 25513-25525. [CrossRef]

23. Waste Resources Action Plan (WRAP). Achieving Good Practice Waste Minimization and Management: Guidance for Construction Clients, Design Teams and Contractors. 2007. Available online: www.wrap.org.uk/construction (accessed on 29 November 2020).

24. Poon, C.S.; Yu, A.T.; Jaillon, L. Reducing building waste at construction sites in Hong Kong. J. Constr. Manag. Econ. 2004, 22, 461-470. [CrossRef]

25. Kofoworola, O.F.; Gheewala, S.H. Estimation of construction waste generation and management in Thailand. Waste Manag. 2009, 29, 731-738. [CrossRef]

26. European Environmental Agency (EEA). Municipal Waste Management across European Countries. 2019. Available online: https:/ / www.eea.europa.eu/publications/emep-eea-guidebook (accessed on 12 December 2020).

27. Garba, A.; Olaleye, Y.O.; Jibrin, N.S. Material resources optimization for sustainable construction in Nigeria. J. Eng. Archit. 2016, 4, 33-47. [CrossRef]

28. Garas, G.L.; Anis, A.R.; Gammal, A.E. Materials waste in the Egyptian construction industry. In Proceedings of the IGLC-9, Rent Ridge Crescent, Singapore, 6-11 August 2001. 
29. Adafin, J.K.; Daramola, O.; Ayodele, E.O. A study of material control strategies in some selected construction firms in Nigeria. Cont. J. Appl. Sci. 2010, 1, 62-72.

30. Adebayo, W.O.; Bamisaye, J.A.; Akintan, O.B.; Ogunleye, O.S. Waste generation, disposal management technique in an urbanizing environment: A case study of Ado-Ekiti, Nigeria. Res. J. Appl. Sci. 2012, 1, 66.

31. Aderibigbe, Y.W.; Ataguba, O.C.; Sheyin, Y. Minimization of wastage of material on construction sites in Nigeria. Int. J. Adv. Acad. Res. 2017, 3, 1-15. [CrossRef]

32. Adewuyi, T.O.; Odesola, I.A. Material waste minimisation strategies among construction firms in South-South, Nigeria. Int. J. Sustain. Constr. Eng. Technol. 2016, 7, 11-29.

33. Adewuyi, T.O.; Idoro, G.I.; Ikpo, I.J. Empirical Evaluation of Construction Material Waste Generated on Sites in Nigeria. J. Civ. Eng. Sci. Appl. 2014, 16, 96-103. [CrossRef]

34. Agamuthu, P.; Hamid, F.S.; Khidzir, K. Evolution of solid waste management in Malaysia: Impacts and Implications of the Solid Waste Bill 2007. J. Mater. Cycles Waste Manag. 2009, 11, 96-103. [CrossRef]

35. Ajayi, S.O.; Oyedele, L.O.; Akinade, O.O.; Bilal, M.; Alaka, H.A.; Owolabi, H.A. Optimising material procurement for construction waste minimization: An exploration of success factors. Sustain. Mater. Technol. 2017, 11, 38-46. [CrossRef]

36. Popoola, O.; Adeleke, J.; Ayegbokiki, S. An investigation into material wastage on building construction sites (case study of selected building construction sites in Osun state). Int. J. Sci. Eng. Environ. Technol. 2018, 3, 18-26.

37. Akanni, P.O. An empirical survey of the effect of materials wastage on contractors' profit level in construction projects. prof. build. J. Niger. Inst. Build. 2007, 35-46. [CrossRef]

38. Akinkurolere, O.O.; Franklin, S.O. Investigation into waste management on construction sites in South Western Nigeria. Am. J. Appl. Sci. 2005, 2, 980-984. [CrossRef]

39. Akinade, O.O.; Oyedele, L.O.; Ajayi, S.O.; Bilal, M.; Alaka, H.A.; Owolabi, H.A.; Bello, S.A.; Jaiyeoba, B.E.; Kadiri, K.O. Design for Deconstruction (DfD): Critical success factors for diverting end-of-life waste from landfills. J. Waste Manag. 2017, 60, 3-13. [CrossRef]

40. Aniramu, O.; Adetoro, O.; Salami, A. An integrated assessment of waste materials generation and waste minimization strategy appraisal in Ikogosi township, Nigeria. Int. J. Res. Sci. Innov. 2019, VI, 20-24.

41. Ajayi, O.M.; Koleoso, H.A.; Soyingbe, A.A.; Oladiran, O.J. The practice of waste management in construction sites in Lagos state; Nigeria. In Proceedings of the Construction and Building Research Conference of the Royal Institution of Chartered Surveyors, Kaduna, Nigeria, 4 September 2008.

42. Akujieze, C.N.; Idehai, I.M. Standardization of the electricity and economics potentials of landfill gas in Lagos, Nigeria. Internat J. Sci. Eng. 2014, 7, 1-9. [CrossRef]

43. Idris, A.; Inanc, B.; Hassan, M.N. Overview of waste disposal and landfills/dumps in Asian countries. J. Mater. Cycles Waste Manag. 2004, 6, 104-110. [CrossRef]

44. Odediran, S.J.; Adeyinka, B.F.; Opatunji, O.A.; Morakinyo, K.O. Business structure of indigenous firms in the Nigerian construction industry. Int. J. Bus. Res. Manag. 2012, 3, 255-264.

45. Odewumi, S.G. Appraisal of storage and collection strategies of municipal solid waste in Lagos State. Hum. Soc. Sci. 2013, 10, 61-67. [CrossRef]

46. Odusami, K.T.; Oladiran, O.J.; Ibrahim, S.A. Evaluation of Materials Wastage and Control in some Selected Building Sites in Nigeria. Emir. J. Eng. Res. 2012, 17, 53-65.

47. Ogunmakinde, O.E.; Sher, W.; Maund, K. An assessment of material waste disposal methods in the Nigerian construction industry. Recycl. J. 2019, 4, 13. [CrossRef]

48. Oladiran, O.J.; Ogunsanmi, O.E.; Dada, M.O. Frameworks for material waste minimization on Nigerian building projects. J. Bus. Manag. 2019, 3, 45-61. [CrossRef]

49. Idehai, I.M.; Adegboyega, R.T. Aspects of geo-mathematical diagnoses and prognoses from physiochemical analyses in landfills and other areas of Lagos, Nigeria. J. Appl. Sci. Environ. Manag. 2014, 18, 11-16. [CrossRef]

50. Creswell, J.W. Research Design: Qualitative, Quantitative and Mixed Methods Approaches, 4th ed.; Sage Publication: London, UK, 2014.

51. Neuman, W.L. Social Research Methods: Qualitative and Quantitative Approaches, 7th ed.; Allyn and Bacon: London, UK, 2014; pp. 45-68.

52. Pallant, J. SPSS Survival Manual: A Step-by-Step Guide to Data Analysis Using SPSS Program, 6th ed.; McGraw-Hill Education: London, UK, 2016. 